See discussions, stats, and author profiles for this publication at: https://www.researchgate.net/publication/341631630

\title{
Study on the Acceptability of an ICT Platform for Older Adults with Mild Cognitive Impairment
}

Article in Journal of Medical Systems · May 2020

DOI: 10.1007/s10916-020-01566-x

CITATIONS

10 authors, including:

Eider Irazoki

Universidad de Salamanca

8 PUBLICATIONS 9 CITATIONS

SEE PROFILE

José Miguel Toribio-Guzmán

Intras Foundation

34 PUBLICATIONS 88 CITATIONS

SEE PROFILE
READS

57

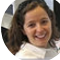

Diana Castilla

University of Zaragoza

63 PUBLICATIONS 553 CITATIONS

SEE PROFILE

Esther Parra Vidales

Universidad de Salamanca

24 PUBLICATIONS 169 CITATIONS

SEE PROFILE

Some of the authors of this publication are also working on these related projects:

ANALISIS DE EFICIENCIA Y SOSTENIBILIDAD DEL METODO RETICULAR DE ATENCION EN SALUD MENTAL Y ESTRATEGIA DE MEJORA View PrOject

Technologies for improving community socio-Health care. View project 


\title{
Study on the Acceptability of an ICT Platform for Older Adults with Mild Cognitive Impairment
}

\author{
Leslie María Contreras-Somoza ${ }^{1,2,3} \cdot$ Eider Irazoki $^{1,2} \cdot$ Diana Castilla $^{4,5} \cdot$ Cristina Botella $^{5,6}$. \\ José Miguel Toribio-Guzmán ${ }^{2}$ • Esther Parra-Vidales ${ }^{2}$ - Carlos Suso-Ribera ${ }^{6}$ - Pilar Suárez-López ${ }^{7}$. \\ María Victoria Perea-Bartolomé ${ }^{1}$. Manuel Ángel Franco-Martín ${ }^{1,8,9}$
}

Received: 26 February 2019 / Accepted: 31 March 2020

(C) Springer Science+Business Media, LLC, part of Springer Nature 2020

\begin{abstract}
EhcoBUTLER is an Information and Communication Technology (ICT) solution funded by the European Union (H2020; ID: 643566) and intended especially for elderly people with mild cognitive impairment (MCI) to improve their health, independence and quality of life, particularly at the social level. The purpose of this study is to assess the acceptability of ehcoBUTLER based on a survey delivered to potential users and actors involved in their care, exploring their expectations and preferences, while anticipating the system's functional requirements. The survey was delivered online to 313 participants (11\% end users, $25 \%$ informal caregivers, $48 \%$ formal caregivers and $16 \%$ administration/management staff) from eight countries. Participants rated the different functionalities of ehcoBUTLER positively, $86.1 \%$ perceiving it as an interesting and useful system. Likewise, they assessed it as a commercially attractive product $(75.1 \%)$. End users expressed a stronger preference for the social module. Nevertheless, they would be ready to pay a low monthly price for ehcoBUTLER. Professionals would be willing to pay choosing its functionalities modularly, but they would also expect it to be funded by the National Health System, centres or businesses. The conclusion is that all participants found ehcoBUTLER interesting, useful and ergonomic. However, to effectively implement it, it is necessary to bridge the digital gap and address the issue of insufficient investment in products aimed at older adults with cognitive impairment. To supplement cognitive training systems with social, emotional or entertainment functionalities could improve adherence to their use.
\end{abstract}

Keywords Acceptability $\cdot$ ICT $\cdot$ Psychosocial stimulation $\cdot$ Cognitive training $\cdot$ Older adults $\cdot$ MCI

This article is part of the Topical Collection on Patient Facing Systems

Leslie María Contreras-Somoza

lesliecontreras@usal.es

1 Faculty of Psychology, University of Salamanca, Salamanca, Spain

2 Department of Research and Development, Iberian Institute of Research in Psycho-Sciences, INTRAS Foundation, Zamora, Spain

3 Fundación INTRAS, Ctra. de la Hiniesta 137, 49024 Zamora, Spain

4 Department of Personality, Evaluation and Psychological Treatment, University of Valencia, Valencia, Spain

5 CIBER Physiopathology, Obesity and Nutrition (CIBERobn), Carlos III Health Institute, Santiago de Compostela, Spain

6 Department of Basic Psychology, Clinic and Psychobiology, University of Jaume I, Castellón, Spain

7 Innovation and Care Development, S.L., Pamplona, Spain

8 Río Hortega Hospital's Psychiatry and Mental Health Service, Valladolid, Spain

9 Zamora Public Welfare Complex, Zamora, Spain

\section{Introduction}

The world population is ageing [1] and it impacts on social welfare, government finances and labour markets [2]. A common characteristic of ageing is the onset of physical or cognitive problems [3]. Forms of mild cognitive impairment (MCI) are common [4]: epidemiological studies on MCI in different continents show a prevalence between $5.0 \%-36.7 \%$ [5]. MCI is often found to be a transitional stage between normal aging and dementia [6], and can result in memory loss or distraction issues [7]. The next step from cognitive impairment is dementia, which is characterized by increased memory loss, decreased attention span and loss of skills for performing daily activities [8].

Older people are also vulnerable to social isolation $[9,10]$, which poses a threat to independent living [11] and increases their mortality [12]. Lack of social interaction can be a consequence of the onset of cognitive and physical impairment, retirement, death of loved ones, living on their own or in institutions [13]. It is essential, therefore, to promote healthy 
Table 1 Services and applications of the ehcoBUTLER system

\begin{tabular}{lll}
\hline Service & Goal & Applications within the service \\
\hline Emotional tools [28] & $\begin{array}{c}\text { Early prevention and detection of anxiety } \\
\text { and/or depression symptoms }\end{array}$ & $\begin{array}{l}\text { Screening for Anxiety/Depression } \\
\text { My Memories } \\
\text { Cheerful and Relaxing Nature } \\
\text { Book of Life } \\
\text { Videoconference } \\
\text { E-mail }\end{array}$ \\
Social tools [29] & Foster social relationships and increase social capital & Friend Search \\
& & News \\
& & Social Profile \\
& & Share on Book of Life \\
Leisure tools [29] & Facilitate access to new Internet applications & EhcoBUTLER Compatible Apps Market \\
& & Internet Access \\
Cognitive training tools [31, 32] & Bookmarks \\
Lifestyle [33-35] & Leisure tools for prevention & Therapy GRADIOR \\
& Professional tools for intervention & Nutrition \\
Ergonomics [36, 37] & Promote healthy lifestyles & Fall Detection \\
& & Activity Calendar
\end{tabular}

ageing and optimize social participation [14]. This justifies the developing tools aimed at fostering social interaction as well as cognitive stimulation and training to improve the elderly population's quality of life $[15,16]$.

Information and Communication Technologies (ICT) are currently known to be useful to reduce social isolation in the elderly by allowing them keep in touch with the outside world, gain social support, participate in activities and boost their self-confidence $[17,18]$. Furthermore, older adults who use

Table 2 Modules for each stakeholder

\begin{tabular}{ll}
\hline Stakeholders & Modules \\
\hline End users & Ergonomic design \\
& Free time and leisure module \\
& Cognitive module \\
& Lifestyle model \\
& Emotional care model \\
& Social care module \\
& Main module for patient management and \\
& telecare \\
& Lifestyle management module \\
& Physical training management module \\
& Module for the management of emotional \\
Formal caregivers & monitoring \\
& Module for the management of social \\
& networking tools \\
& Module for the management of cognitive \\
& training \\
& Support for the family care module \\
Social module for families \\
Management of the centre \\
Administration and & Patient management module \\
management staff & Free time and leisure management module \\
& Module for the management of cognitive \\
& training tools \\
& Multimedia management module \\
&
\end{tabular}

computers have been observed to be at a lower risk of receiving a diagnosis of dementia up to 8.5 years later [19].

EhcoBUTLER is an ICT platform in development, aimed at facing the challenge of active and healthy aging, especially in elderly with MCI at social level, with different services and modules in which each user can choose the tools that they wish to use. However, its potential benefits can be negatively affected by social issues, interest, motivation, cognitive/physical capacity or the place where they live [16], so it is necessary to examine variables that allow predicting the acceptability that its functionalities will have in the direct and indirect users. The Technology Acceptance Model provides the theoretical background for a methodology to assess users' acceptance [20]. The variables perceived ease-of-use and perceived usefulness are important in the shaping of attitudes, behavioural intention and final decision to use the technology concerned [21, 22]. The elderly's acceptance

Table 3 Variables measured for all users

\begin{tabular}{|c|c|}
\hline Variable & Response scale \\
\hline Interest as a system & $0-10(0=$ None, $10=$ High $)$ \\
\hline Perceived usefulness & $0-10(0=$ None, $10=$ High $)$ \\
\hline Future purchase intention & $0-4(0=$ Definitely not, $4=$ Very probably $)$ \\
\hline $\begin{array}{l}\text { Interest in purchasing } \\
\text { hardware }\end{array}$ & $\begin{array}{l}\text { a. I would rather use my own } \\
\text { b. I would rather have all the devices installed } \\
\text { (computer, touchscreen, ergonomic } \\
\text { keyboard, etc.) }\end{array}$ \\
\hline $\begin{array}{l}\text { How much would you pay } \\
\text { for the system? }\end{array}$ & Open question \\
\hline Interest as a product & $\begin{array}{l}\text { a. Yes, I think it's interesting } \\
\text { b. No, I don't need it } \\
\text { c. No, it's too complex } \\
\text { d. No, I wouldn't pay for the hardware } \\
\text { e. Other }\end{array}$ \\
\hline
\end{tabular}


Fig. 1 Stakeholders sample

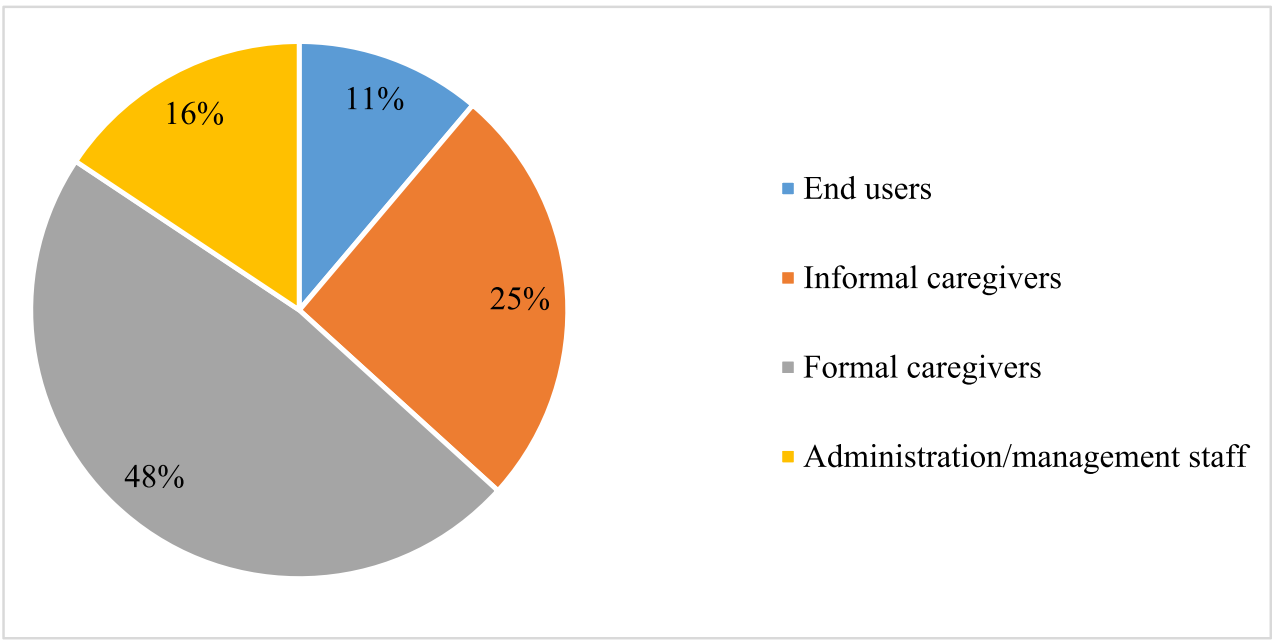

of technology is also influenced by reliability, cost and technological expertise [23]. Therefore, it is crucial for technologies, like ehcoBUTLER, to be developed according to user's needs, abilities and interests. Likewise, helping older people to bridge the digital divide will bring greater integration and will benefit all society [24].

The purpose of this study is to assess the acceptability of ehcoBUTLER by means of a survey delivered to potential users and actors involved in their care, as essential part of its development in the European project.

\section{Method}

This qualitative study was based on an ad hoc online survey, because it allows gathering and analyzing information of the characteristics and attributes of a larger representative sample [25] which, in line with the human-centred design, will enable the identification of system's functional requirements and develop an useful and acceptable technological tool according to the needs and conditions of users and interested actors [26].

\section{Participants}

The survey was completed by 375 individuals. To recruit them, each project partner selected representative users who were going to be subjected to the tool (business model). Therefore, the sample conformed was naturalistic of each partner, in which 5 partners were from Spain, 2 from Italy and 1 from Greece, Netherlands, Slovenia, France, Serbia and Israel respectively. The participants were categorized into end users, informal caregivers, formal caregivers and administration/management staff.

\section{Inclusion criteria}

- End users: individuals over the age of 60 with MCI who had obtained scores between 23 and 27 on the MiniMental State Examination (MMSE) [27].
Fig. 2 Stakeholders' interest and perceived usefulness for ehcoBUTLER

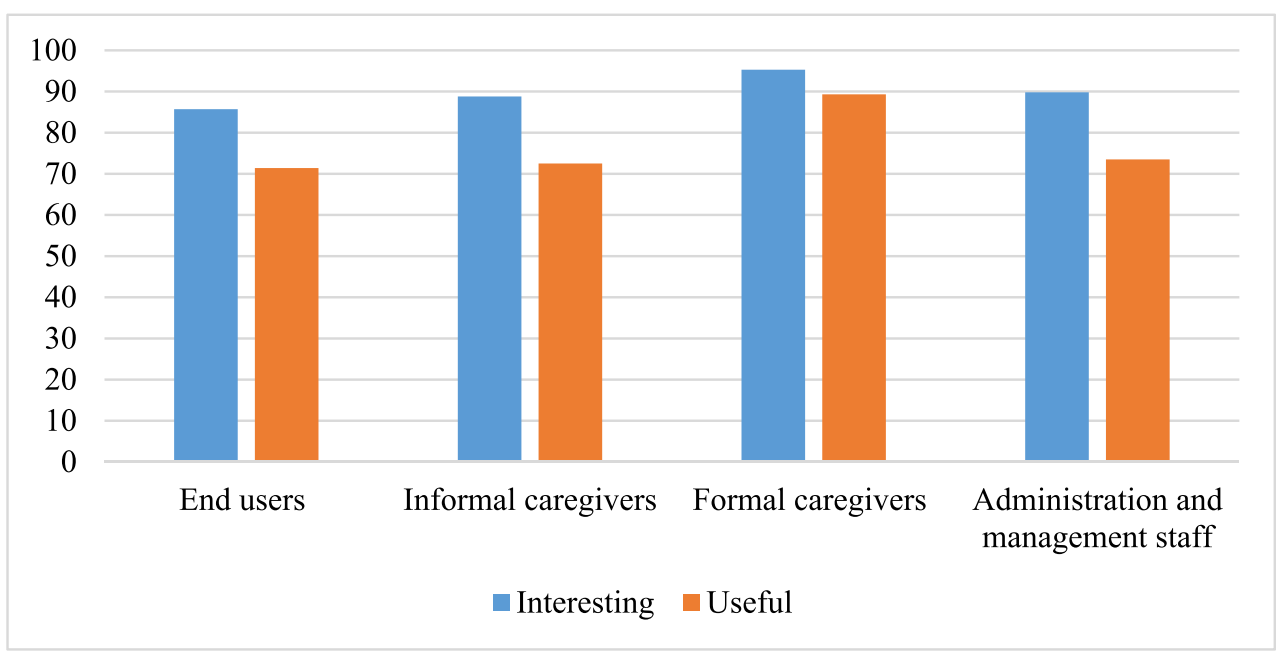


Table 4 Stakeholders' ehcoBUTLER purchase probabilities

\begin{tabular}{llllll}
\hline & Purchase probability & End users & Informal caregivers & Formal caregivers & Administration/management staff \\
\hline Negative score & Not at all likely & $1(2.9 \%)$ & $2(2.5 \%)$ & $2(1.3 \%)$ & $1(2.0 \%)$ \\
& Unlikely & $5(14.3 \%)$ & $15(18.8 \%)$ & $16(10.7 \%)$ & $2(4.1 \%)$ \\
& I don't know & $11(31.4 \%)$ & $15(18.8 \%)$ & $44(29.5 \%)$ & $16(32.7 \%)$ \\
& Total & $17(48.6 \%)$ & $32(40.0 \%)$ & $62(41.6 \%)$ & $19(38.8 \%)$ \\
Positive score & Probable & $14(40.0 \%)$ & $32(40.0 \%)$ & $64(43.0 \%)$ & $18(36.7 \%)$ \\
& Very likely & $4(11.4 \%)$ & $16(20.0 \%)$ & $23(15.4 \%)$ & $12(24.5 \%)$ \\
& Total & $18(51.4 \%)$ & $48(60.0 \%)$ & $87(58.4 \%)$ & $30(61.2 \%)$ \\
\hline
\end{tabular}

- Informal caregivers: family, friends or neighbours providing care and support to elderly with MCI.

- Formal caregivers: individuals with professional qualifications or training to meet the needs of the elderly population (social workers, healthcare providers, people in the area of social welfare, outpatient care, members of activity centres or charities).

- Administration/management staff: people whose role consists of administering and facilitating their products/ services to the elderly population (telehealth/telecare companies, hospitals and insurance companies).

\section{Materials}

\section{Online survey}

An ad hoc online survey was produced for each stakeholder with the purpose of exploring their general views on ehcoBUTLER. End users were administered a version that also assessed their opinion of each module. Sociodemographic data were collected from all participants. The survey was developed using SurveyMonkey cloud-based software (https://es.surveymonkey. com/r/QYW6ST6).

\section{Video demonstration}

The versions of the survey included an initial video displaying all the functionalities and customized modules of ehcoBUTLER. Table 1 shows the services and applications offered by it. Most of these have been validated in previous studies and refactored to fit this project:

\section{Procedure}

\section{Survey preparation and dissemination}

An ad hoc online survey was developed for this study, including variables that indicated interest in the tool [36], perceived usefulness and economic parameters for the analysis of marketing opportunities. Finally, there were questions to gather qualitative information about ehcoBUTLER.

The survey was developed in English and each partner translated it into the official language of its country (Spanish, Dutch, French, Italian, Greek, Hebrew, Serbian and Slovenian). Subsequently, SurveyMonkey was used to distribute the survey in each country. Each partner prepared a list of potential users according to their own business model. Stakeholders were contacted via an e-mail requesting their participation in the survey through a personalized link. When such means was not available or was not the most suitable method of contact, psychologists/team partners conducted telephone or face-to-face interviews asking for their participation and assessment. Respondents were selected through convenience sampling.

\section{Description of the Survey}

The introduction to the survey consisted of a video demonstration of ehcoBUTLER and its modules, explaining the
Table 5 Stakeholders' preferences for using their own devices or for ehcoBUTLER to provide them

\begin{tabular}{llll}
\hline Stakeholders & Use their own devices & Use ehcoBUTLER devices & No answer \\
\hline End users & $15(42.9 \%)$ & $16(45.7 \%)$ & $4(11.4 \%)$ \\
Informal caregivers & $44(55.0 \%)$ & $29(36.3 \%)$ & $7(8.8 \%)$ \\
Formal caregivers & $66(44.3 \%)$ & $79(53.0 \%)$ & $4(2.7 \%)$ \\
Administration /management staff & $14(28.6 \%)$ & $30(61.2 \%)$ & $5(10.2 \%)$ \\
Total & $139(44.4 \%)$ & $154(49.2 \%)$ & $20(6.4 \%)$ \\
\hline
\end{tabular}


Table 6 Intention to purchase the ehcoBUTLER system

\begin{tabular}{llll}
\hline & $\mathrm{n}(\%)$ & $\begin{array}{l}\text { Amount } \\
\text { willing to pay }\end{array}$ & $\begin{array}{l}\text { Do not } \\
\text { know }(\%)\end{array}$ \\
\hline End users & $30(85.7 \%)$ & $9.50 € /$ month & $5(14.3 \%)$ \\
Informal caregivers & $73(91.3 \%)$ & $20 € /$ month & $7(8.8 \%)$ \\
Formal caregivers & $98(65.8 \%)$ & $35 € /$ month & $51(34.2 \%)$ \\
Administration/management staff & $37(75.5 \%)$ & $50 € /$ month & $12(24.5 \%)$ \\
\hline
\end{tabular}

Note: $\mathbf{n}=$ Sample

purpose, main features and details of the design. This was followed by the collection of sociodemographic data. Subsequently, the versions of the survey were delivered according to user type and all included a brief description of ehcoBUTLER's modules, which was different for each of the stakeholders (Table 2).

All stakeholders were required to give their general opinion of the platform in the survey, which included 5 questions (Table 3).

End users were additionally required to assess each module using 5 categories (interesting, useful, necessary, satisfies your needs and improves the care you receive) on a 6-point Likert scale $(0=$ Not at all; $6=$ Absolutely) (Appendix, Table 14). This is how whether there were any modules requiring adaptations according to end users' needs and expectations was explored.

\section{Results}

\section{Participants}

Of the 375 individuals who completed the survey, 62 were excluded from the analysis: 56 for incomplete data and 6 end users for not meeting the MMSE score inclusion criterion. Analyses were conducted on the basis of the answers obtained from 313 participants, most of them were formal caregivers as shown in Fig. 1.

Most of the participants were Spanish women with university qualifications. The average age for caregivers and administration/management staff was $44.6( \pm 12.3)$, while that of end users was $76.3( \pm 8.3)$. Most of the latter and of the formal caregivers coincided in having income levels between 10,000 and $20,000 €$. Only part of the informal caregivers was within such income range, while another coincided with the standard income of administration/management staff (between 20,000 and 40,000 €) (Appendix, Table 15).

\section{General survey}

To improve understanding of the results, scores were divided into positive and negative. The results of the general survey show high means of positive scores in all ehcoBUTLER modules: $91.7 \%$ of the participants considered it to be an interesting system and $80.5 \%$ assessed it as useful (Fig. 2).

Most of the participants (58.5\%) showed an interest in buying ehcoBUTLER, especially formal caregivers, followed by informal caregivers, administration/management staff and end users (Table 4).

Most formal carers and administration/management staff would rather ehcoBUTLER provided them with the hardware required to use the platform. Half of the end users also preferred this option, but informal caregivers would rather use their own devices (Table 5).

$76 \%$ of the stakeholders $(n=238)$ would be willing to pay monthly for having ehcoBUTLER. Administration/ management staff was willing to pay the highest amount for it, while end users would pay the least (Table 6).

Among the participants who were uncertain of how much they would be prepared to pay $(n=75,24 \%)$, formal caregivers had the greatest difficulty in deciding, invoking reasons such as that the price would depend on the number of modules and usefulness, or that they expected the programme to be financed by the National Health System (NHS), centres or companies.

As for ehcoBUTLER's commercial potential, most of stakeholders believed that it was an interesting product. Formal caregivers showed the highest interest, followed by informal caregivers, administration/management staff and end users (Table 7).

Table 7 Stakeholders' perception of ehcoBUTLER as an interesting product

\begin{tabular}{|c|c|c|c|c|c|c|}
\hline Stakeholders & Yes, it's interesting & No, I don't need it & No, it's complicated & No, you must pay & Other & No answer \\
\hline End users & $27(77.1 \%)$ & 0 & $1(2.9 \%)$ & $1(2.9 \%)$ & $2(5.7 \%)$ & $4(11.4 \%)$ \\
\hline Informal caregivers & $60(75.0 \%)$ & $4(5.0 \%)$ & $4(5.0 \%)$ & $4(5.0 \%)$ & $1(1.3 \%)$ & $7(8.8 \%)$ \\
\hline Formal caregivers & $112(75.2 \%)$ & $16(10.7 \%)$ & $2(1.3 \%)$ & $11(7.4 \%)$ & $3(2.0 \%)$ & $5(3.4 \%)$ \\
\hline Administration/management staff & $36(73.5 \%)$ & $1(2.0 \%)$ & $1(2.0 \%)$ & $2(4.1 \%)$ & $3(6.1 \%)$ & $6(12.2 \%)$ \\
\hline Total & $235(75.1 \%)$ & $21(6.7 \%)$ & $8(2.6 \%)$ & $18(5.8 \%)$ & $9(2.9 \%)$ & $22(7.0 \%)$ \\
\hline
\end{tabular}




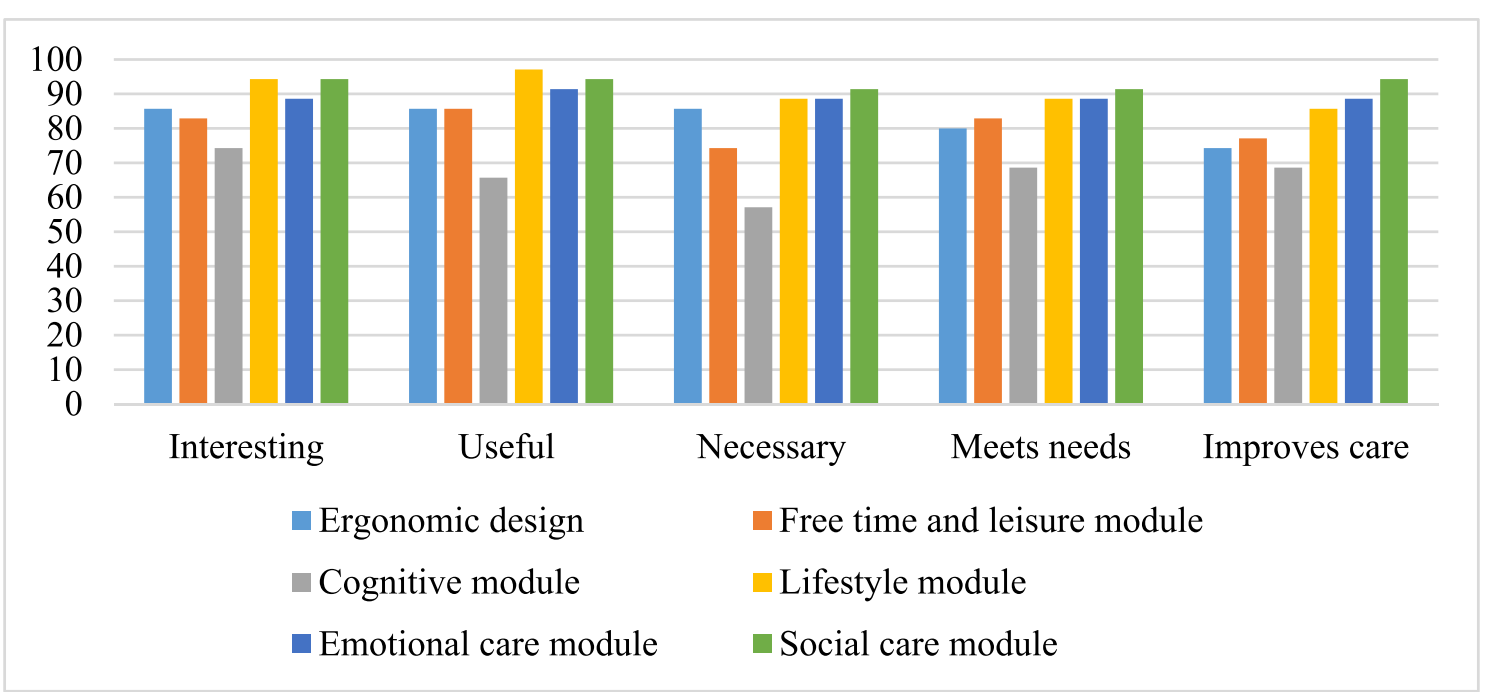

Fig. 3 End users' assessment for each module

\section{End User Survey}

End users were surveyed on each ehcoBUTLER's module, assessing on a 6-point Likert scale the following categories for each module: interest, usefulness, need for such service, extent to which it meets their needs and improvement in the care they are receiving (Appendix, Table 14). To make understanding of the results easier, scores were divided into negative (0-3) and positive (4-6).

All modules achieved positive scores. The social care module scored the highest, with $93.1 \%$ of the users assessing it positively, while the cognitive module was assessed positively by $66.9 \%$ of the users (Fig. 3).

As regards categories, all modules generally received very positive scores, with interesting (86.6\%) and useful (86.6\%) scoring the highest, while necessary achieved $80.9 \%$. (Fig. 3).

As regards ehcoBUTLER's ergonomic design, intended for easy and autonomous usage, most end users agreed that it was interesting, useful and necessary ( $85.7 \%$ in all cases). The second place was taken by their considering that it could meet their needs and, in the third place was that it would improve the care they were receiving (Table 8).

The free time and leisure module, designed to foster participation in different activities, was mostly assessed as useful by end users $(85.7 \%)$. In second place, they agreed that it was interesting and might meet their needs, in third place came that it could improve their care, and last of all, their belief that it was necessary (Table 9).

End users made a positive assessment of the cognitive module, aimed at facilitating exercises designed and supervised by professionals to train cognition. The category interesting was the most positively valued (74.3\%), followed by the claim that it could meet their needs and that it could improve the care they were receiving. Next came useful and, last, necessary (Table 10).

The lifestyle module, aimed at supporting the performance of everyday activities, was assessed by end users as useful (97.1\%). Second came the category of interesting, and third those of necessary and capable of meeting their needs. Improvement of their care came last (Table 11).

Table 8 End users' opinion on the ergonomic design of ehcoBUTLER

\begin{tabular}{|c|c|c|c|c|c|c|c|}
\hline \multicolumn{3}{|c|}{ Ergonomic design } & \multirow{2}{*}{$\begin{array}{l}\text { Interesting } \\
0\end{array}$} & \multirow{2}{*}{$\begin{array}{l}\text { Useful } \\
0\end{array}$} & \multirow{2}{*}{$\frac{\text { Necessary }}{1(2.9 \%)}$} & \multirow{2}{*}{$\begin{array}{l}\text { Meets needs } \\
0\end{array}$} & \multirow{2}{*}{$\begin{array}{l}\text { Improves care } \\
1(2.9 \%)\end{array}$} \\
\hline Negative score & 0 & Not at all & & & & & \\
\hline & 1 & Hardly & 0 & $1(2.9 \%)$ & 0 & $1(2.9 \%)$ & $1(2.9 \%)$ \\
\hline & 2 & Not much & $1(2.9 \%)$ & 0 & $3(8.6 \%)$ & $2(5.7 \%)$ & $4(11.4 \%)$ \\
\hline & 3 & Somewhat & $4(11.4 \%)$ & $4(11.4 \%)$ & $1(2.9 \%)$ & $4(11.4 \%)$ & $3(8.6 \%)$ \\
\hline & Total & & $5(14.3 \%)$ & $5(14.3 \%)$ & $5(14.3 \%)$ & $7(20.0 \%)$ & $9(25.7 \%)$ \\
\hline \multirow[t]{4}{*}{ Positive score } & 4 & Sufficient & $10(28.6 \%)$ & $13(37.1 \%)$ & $11(31.4 \%)$ & $13(37.1 \%)$ & $9(25.7 \%)$ \\
\hline & 5 & A lot & $10(28.6 \%)$ & $8(22.9 \%)$ & $13(37.1 \%)$ & $9(25.7 \%)$ & $8(22.9 \%)$ \\
\hline & 6 & Absolutely & $10(28.6 \%)$ & $9(25.7 \%)$ & $6(17.1 \%)$ & $6(17.1 \%)$ & $9(25.7 \%)$ \\
\hline & Total & & $30(85.7 \%)$ & $30(85.7 \%)$ & $30(85.7 \%)$ & $28(80.0 \%)$ & $26(74.3 \%)$ \\
\hline
\end{tabular}


Table 9 End users' opinion on ehcoBUTLER's free time and leisure module

\begin{tabular}{|c|c|c|c|c|c|c|c|}
\hline \multicolumn{3}{|c|}{ Free time and leisure module } & \multirow{2}{*}{$\begin{array}{l}\text { Interesting } \\
0\end{array}$} & \multirow{2}{*}{$\frac{\text { Useful }}{0}$} & \multirow{2}{*}{$\begin{array}{l}\text { Necessary } \\
1(2.9 \%)\end{array}$} & \multirow{2}{*}{$\begin{array}{l}\text { Meets needs } \\
0\end{array}$} & \multirow{2}{*}{$\begin{array}{l}\text { Improves care } \\
1(2.9 \%)\end{array}$} \\
\hline Negative score & 0 & Not at all & & & & & \\
\hline & 1 & Hardly & $1(2.9 \%)$ & $1(2.9 \%)$ & 0 & 0 & 0 \\
\hline & 2 & Not much & $2(5.7 \%)$ & $1(2.9 \%)$ & $3(8.6 \%)$ & $1(2.9 \%)$ & $1(2.9 \%)$ \\
\hline & 3 & Somewhat & $3(8.6 \%)$ & $3(8.6 \%)$ & $5(14.3 \%)$ & $5(14.3 \%)$ & $6(17.1 \%)$ \\
\hline & Total & & $6(17.1 \%)$ & $5(14.3 \%)$ & $9(25.7 \%)$ & $6(17.1 \%)$ & $8(22.9 \%)$ \\
\hline \multirow[t]{4}{*}{ Positive score } & 4 & Sufficient & $10(28.6 \%)$ & $10(28.6 \%)$ & $7(20.0 \%)$ & $11(31.4 \%)$ & $9(25.7 \%)$ \\
\hline & 5 & A lot & $13(37.1 \%)$ & $13(37.1 \%)$ & $14(40.0 \%)$ & $11(31.4 \%)$ & $11(31.4 \%)$ \\
\hline & 6 & Absolutely & $6(17.1 \%)$ & $7(20.0 \%)$ & $5(14.3 \%)$ & $7(20.0 \%)$ & $7(20.0 \%)$ \\
\hline & Total & & $29(82.9 \%)$ & $30(85.7 \%)$ & $26(74.3 \%)$ & $29(82.9 \%)$ & $27(77.1 \%)$ \\
\hline
\end{tabular}

The emotional care module, which includes activities aimed at improving mood and fostering positive feelings, was positively assessed by end users. Most of them (91.4\%) thought it was useful and coincided in the rest of scores qualifying it as interesting, necessary, capable of meeting their needs and capable of improving the care they were receiving (Table 12).

The social care module includes tools suitable for elderly people that will allow them to communicate with others via the Internet. Most end users considered it interesting, useful and capable of improving their care (94.3\% respectively). They also assessed it as necessary and capable of meeting their needs (Table 13).

\section{Discussion}

An ad hoc survey was prepared for the purpose of this study and delivered online to learn the degree of acceptability of ehcoBUTLER by elderly people with MCI and by all those involved in their care. EhcoBUTLER is an ICT platform that is currently under development and whose aim is to promote health, independence and quality of life, though mainly at the social level, in elderly people with MCI. The survey was conducted in different countries and respondents were potential direct users (end users with $\mathrm{MCI}$ ) and indirect users (formal/ informal caregivers and administration/management staff), with the purpose of involving them in the development of what is required from ehcoBUTLER.

The findings show that ehcoBUTLER was well accepted as an interesting and useful platform by all the participants. In the general survey, formal caregivers allocated the highest positive scores in such categories: $95.3 \%$ assessed it as interesting and $89.3 \%$ as useful. This information is relevant, since good acceptance by professionals is essential for any technology's implementation in the healthcare area [37]. In the end users' survey version, the categories of interesting and useful also obtained high positive scores ( $86.6 \%$ respectively). This study is in line with other studies in that the development of new technologies such as ehcoBUTLER may appeal to the elderly population. There is evidence that elderly people tend express high interest in technologies for cognitive stimulation [38] and training [39]. Moreover, users with cognitive impairment perceive cognitive and social support technologies as the most useful tools, also expressing greater willingness to use them [40].

Table 10 End users' opinion on ehcoBUTLER's cognitive module

\begin{tabular}{|c|c|c|c|c|c|c|c|}
\hline \multicolumn{3}{|l|}{ Cognitive module } & \multirow{2}{*}{$\begin{array}{l}\text { Interesting } \\
2(5.7 \%)\end{array}$} & \multirow{2}{*}{$\frac{\text { Useful }}{1(2.9 \%)}$} & \multirow{2}{*}{$\begin{array}{l}\text { Necessary } \\
2(5.7 \%)\end{array}$} & \multirow{2}{*}{$\begin{array}{l}\text { Meets needs } \\
1(2.9 \%)\end{array}$} & \multirow{2}{*}{$\begin{array}{l}\text { Improves care } \\
1(2.9 \%)\end{array}$} \\
\hline Negative score & 0 & Not at all & & & & & \\
\hline & 1 & Hardly & $2(5.7 \%)$ & $2(5.7 \%)$ & $2(5.7 \%)$ & $2(5.7 \%)$ & $3(8.6 \%)$ \\
\hline & 2 & Not much & $3(8.6 \%)$ & $4(11.4 \%)$ & $6(17.1 \%)$ & $6(17.1 \%)$ & $6(17.1 \%)$ \\
\hline & 3 & Somewhat & $2(5.7 \%)$ & $5(14.3 \%)$ & $5(14.3 \%)$ & $2(5.7 \%)$ & $1(2.9 \%)$ \\
\hline & Total & & $9(25.7 \%)$ & $12(34.3 \%)$ & $15(42.9 \%)$ & $11(31.4 \%)$ & $11(31.4 \%)$ \\
\hline \multirow[t]{4}{*}{ Positive score } & 4 & Sufficient & $12(34.3 \%)$ & $9(25.7 \%)$ & $10(28.6 \%)$ & $11(31.4 \%)$ & $11(31.4 \%)$ \\
\hline & 5 & A lot & $9(25.7 \%)$ & $7(20.0 \%)$ & $7(20.0 \%)$ & $11(31.4 \%)$ & $9(25.7 \%)$ \\
\hline & 6 & Absolutely & $5(14.3 \%)$ & $7(20.0 \%)$ & $3(8.6 \%)$ & $2(5.7 \%)$ & $4(11.4 \%)$ \\
\hline & Total & & $26(74.3 \%)$ & $23(65.7 \%)$ & $20(57.1 \%)$ & $24(68.6 \%)$ & $24(68.6 \%)$ \\
\hline
\end{tabular}


Table 11 End users' opinion on ehcoBUTLER's lifestyle module

\begin{tabular}{|c|c|c|c|c|c|c|c|}
\hline \multicolumn{3}{|l|}{ Lifestyle module } & \multirow{2}{*}{$\begin{array}{l}\text { Interesting } \\
0\end{array}$} & \multirow{2}{*}{$\frac{\text { Useful }}{0}$} & \multirow{2}{*}{$\begin{array}{l}\text { Necessary } \\
0\end{array}$} & \multirow{2}{*}{$\begin{array}{l}\text { Meets needs } \\
0\end{array}$} & \multirow{2}{*}{$\begin{array}{l}\text { Improves care } \\
1(2.9 \%)\end{array}$} \\
\hline Negative score & 0 & Not at all & & & & & \\
\hline & 1 & Hardly & 0 & 0 & 0 & 0 & 0 \\
\hline & 2 & Not much & 0 & 0 & 0 & 0 & 0 \\
\hline & 3 & Somewhat & $2(5.7 \%)$ & $1(2.9 \%)$ & $4(11.4 \%)$ & $4(11.4 \%)$ & $4(11.4 \%)$ \\
\hline & Total & & $2(5.7 \%)$ & $1(2.9 \%)$ & $4(11.4 \%)$ & $4(11.4 \%)$ & $5(14.3 \%)$ \\
\hline \multirow[t]{4}{*}{ Positive score } & 4 & Sufficient & $7(20.0 \%)$ & $10(28.6 \%)$ & $5(14.3 \%)$ & $11(31.4 \%)$ & $9(25.7 \%)$ \\
\hline & 5 & A lot & $17(48.6 \%)$ & $15(42.9 \%)$ & $20(57.1 \%)$ & $13(37.1 \%)$ & $12(34.3 \%)$ \\
\hline & 6 & Absolutely & $9(25.7 \%)$ & $9(25.7 \%)$ & $6(17.1 \%)$ & $7(20.0 \%)$ & $9(25.7 \%)$ \\
\hline & Total & & $33(94.3 \%)$ & $34(97.1 \%)$ & $31(88.6 \%)$ & $31(88.6 \%)$ & $30(85.7 \%)$ \\
\hline
\end{tabular}

On the other hand, while the category of necessary was given a positive score by end users, the rest of categories obtained higher positive scores. The reason for this is that older adults might prefer face-to-face interventions because of the difficulties they find in technologies [41]. Elderly people's lack of experience with technologies reveal the existence of a digital divide, so that education and training in their usage should be a path to bridging it, which is one of ehcoBUTLER's objectives. Likewise, it is important for the design of this technology to focus on the users' perceived needs [40]. In this regard, ehcoBUTLER inherits all its ergonomic design from BUTLER, which in prior studies achieved very positive usability results among seniors [41-42], guiding users by linear navigation and an avatar.

This is endorsed by further studies that maintain that better performance can be expected from older adults (whether healthy or with MCI) if they are provided with a userfriendly introduction [43]. Although the elderly may at first be reluctant to participate for fear of doing it wrong, they can end up enjoying technological tools that motivate them to train their cognitive skills, share their positive experience with family [44] and keep up with the times in an ICT-driven society [45]. The scores achieved by these users on ehcoBUTLER are also encouraging and suggest that its use will be well accepted by its target users.

It is also significant that formal caregivers found the greatest difficulties in deciding the amount they were willing to pay for ehcoBUTLER, stating that they would expect it to be funded by the NHS, centres or companies. This is consistent with the fact that administration/ management staff was willing to pay more for the platform, while end users were less willing to pay. These attitude could be explained by the impoverishment that comes with old age due to the reduction/interruption of labour activities [46]. In this regard, the United Nations [47] called for the collaboration of governments, organizations and the private sector suggesting that technology might contribute to an independent life, reduce loneliness

Table 12 End users' opinion on the emotional care module

\begin{tabular}{|c|c|c|c|c|c|c|c|}
\hline \multicolumn{3}{|c|}{ Emotional care module } & \multirow{2}{*}{$\frac{\text { Interesting }}{1(2.9 \%)}$} & \multirow{2}{*}{$\frac{\text { Useful }}{0}$} & \multirow{2}{*}{$\begin{array}{l}\text { Necessary } \\
0\end{array}$} & \multirow{2}{*}{$\begin{array}{l}\text { Meets needs } \\
0\end{array}$} & \multirow{2}{*}{$\frac{\text { Improves care }}{2(5.7 \%)}$} \\
\hline Negative score & 0 & Not at all & & & & & \\
\hline & 1 & Hardly & 0 & 0 & $1(2.9 \%)$ & 0 & 0 \\
\hline & 2 & Not much & 0 & $2(5.7 \%)$ & $2(5.7 \%)$ & 0 & 0 \\
\hline & 3 & Somewhat & $3(8.6 \%)$ & $1(2.9 \%)$ & $1(2.9 \%)$ & $4(11.4 \%)$ & $2(5.7 \%)$ \\
\hline & Total & & $4(11.4 \%)$ & $3(8.6 \%)$ & $4(11.4 \%)$ & $4(11.4 \%)$ & $4(11.4 \%)$ \\
\hline \multirow[t]{4}{*}{ Positive score } & 4 & Sufficient & $9(25.7 \%)$ & $7(20.0 \%)$ & $11(31.4 \%)$ & $15(42.9 \%)$ & $10(28.6 \%)$ \\
\hline & 5 & A lot & $13(37.1 \%)$ & $16(45.7 \%)$ & $12(34.3 \%)$ & $13(37.1 \%)$ & $18(51.4 \%)$ \\
\hline & 6 & Absolutely & $9(25.7 \%)$ & $9(25.7 \%)$ & $8(22.9 \%)$ & $3(8.6 \%)$ & $3(8.6 \%)$ \\
\hline & Total & & $31(88.6 \%)$ & $32(91.4 \%)$ & $31(88.6 \%)$ & $31(88.6 \%)$ & $31(88.6 \%)$ \\
\hline
\end{tabular}


Table 13 End users' opinion on ehcoBUTLER's social care module

\begin{tabular}{|c|c|c|c|c|c|c|c|}
\hline \multicolumn{3}{|c|}{ Social care module } & \multirow{2}{*}{$\begin{array}{l}\text { Interesting } \\
0\end{array}$} & \multirow{2}{*}{$\frac{\text { Useful }}{0}$} & \multirow{2}{*}{$\frac{\text { Necessary }}{1(2.9 \%)}$} & \multirow{2}{*}{$\frac{\text { Meets needs }}{1(2.9 \%)}$} & \multirow{2}{*}{$\begin{array}{l}\text { Improves care } \\
1(2.9 \%)\end{array}$} \\
\hline Negative score & 0 & Not at all & & & & & \\
\hline & 1 & Hardly & 0 & 0 & 0 & 0 & 0 \\
\hline & 2 & Not much & $2(5.7 \%)$ & $2(5.7 \%)$ & $2(5.7 \%)$ & 0 & 0 \\
\hline & 3 & Somewhat & 0 & 0 & 0 & $2(5.7 \%)$ & $1(2.9 \%)$ \\
\hline & Total & & $2(5.7 \%)$ & $2(5.7 \%)$ & $3(8.6 \%)$ & $3(8.6 \%)$ & $2(5.7 \%)$ \\
\hline \multirow[t]{4}{*}{ Positive score } & 4 & Sufficient & $3(8.6 \%)$ & $7(20.0 \%)$ & $4(11.4 \%)$ & $6(17.1 \%)$ & $8(22.9 \%)$ \\
\hline & 5 & A lot & $14(40.0 \%)$ & $8(22.9 \%)$ & $10(28.6 \%)$ & $15(42.9 \%)$ & $10(28.6 \%)$ \\
\hline & 6 & Absolutely & $16(45.7 \%)$ & $18(51.4 \%)$ & $18(51.4 \%)$ & $11(31.4 \%)$ & $15(42.9 \%)$ \\
\hline & Total & & $33(94.3 \%)$ & $33(94.3 \%)$ & $32(91.4 \%)$ & $32(91.4 \%)$ & $33(94.3 \%)$ \\
\hline
\end{tabular}

and bridge the age gap. Thus, it is necessary to overcome the digital divide and also that of investment in ageing.

Regarding the study of each module, social care scored the highest $(93.1 \%$ ), while the cognitive module obtained a positive score of $66.9 \%$. These results are proof of the usefulness of social participation and relationships [48], which is the main objective of ehcoBUTLER: counter social isolation in people with $\mathrm{MCI}$; and is how potential users also seem to see it. Nevertheless, a clinical trial on GRADIOR (stimulation, training and cognitive rehabilitation programme, which ehcoBUTLER is associated with) has been scheduled to compare the value of psychostimulation through social participation against direct cognitive stimulation and against the association of both.

Conversely, the above result could have been influenced by the fact that most of the sample were women, who have stronger inclinations towards social integration than men [49]. Likewise, women have been found to be more resilient to age-related cognitive impairment [50].

Finally, it is important to consider this study's limitations. First, samples of each stakeholder were unequal in each country, so it was no possible to compare the results per countries. However, samples were free from selection biases and representative of the population for whom the platform was intended, as well as naturalistic of every project partner according to their business models. The high percentage of positive opinions on ehcoBUTLER substantiate that sample increases would have no impact on the rating obtained.

Another limitation is that there have been missing values for certain variables, especially in the questions related to ehcoBUTLER's commercial potential. Nevertheless, even these questions were answered by more than half of the respondents.

\section{Conclusions}

The purpose of this study was to assess the acceptability of ehcoBUTLER. The conclusion drawn is that it is an ergonomic, interesting and useful tool for all the participating users. The social module was considered to be the most useful by older adults, a result that could suggest that clinical tools could improve their acceptability by offering further social functionalities and improving elderly's access to information and social communication skills.

Another important aspect yielded by the study is evidence of an investment gap in products designed for older people with MCI. Care and services for this population requires investment in healthcare tools that may improve autonomy in the use of technologies, so it should be designed according to the capacities of this users and aimed at improving their quality of life at different levels.

Acknowledgements We would like to give special thanks to the ehcoBUTLER project partners who participate collecting data in the stakeholder survey: EVERIS SPAIN SL (Spain), ASISTEL DOO BEOGRAD (Serbia), CLALIT HEALTH SERVICES (Israel), ESENIORS: INITIATION DES SENIORS AUX NTIC ASSOCIATION (France), IDEA- INNOVACIÓN Y DESARROLLO ASISTENCIAL SL (Spain), FUNDACIÓN INTRAS (Spain), SENLAB, DRUZBA ZA INFORMACIJSKO TEHNOLOGIJO, DOO (Slovenia), STICHTING NATIONAAL OUDERENFONDS - Nationaal Ouderenfonds (Netherlands), VIDAVO S.A. (Greece), TELEFÓNICA MÓVILES ESPAÑA S.A. (Spain), AIMA NAPOLI ONLUS (Italy), YOUR DATA SRL (Italy), CENTRO DE INVESTIGACIÓN BIOMÉDICA EN RED - CIBER (Spain).

Funding The ehcoBUTLER project has received funding from the European Union's Horizon 2020 research and innovation programme [Grant Agreement 643566].

\section{Compliance with Ethical Standards}

Conflict of Interest None. 


\section{Appendix}

Table 14 Categories for each module assessed by end users

\begin{tabular}{|c|c|c|c|c|c|c|}
\hline $\begin{array}{l}\text { Not at all } \\
0\end{array}$ & $\begin{array}{l}\text { Hardly } \\
1\end{array}$ & $\begin{array}{l}\text { Not much } \\
2\end{array}$ & $\begin{array}{l}\text { Somewhat } \\
3\end{array}$ & $\begin{array}{l}\text { Sufficient } \\
4\end{array}$ & $\begin{array}{l}\text { A lot } \\
5\end{array}$ & $\begin{array}{l}\text { Absolutely } \\
6\end{array}$ \\
\hline
\end{tabular}

Interesting

Useful

Necessary

Meets target population's needs

Improves care of elderly people in this aspect

Table 15 Stakeholders' sociodemographic characteristics

\begin{tabular}{|c|c|c|c|c|c|}
\hline Stakeholders & Country & n (Sex) & Age (S.D.) & Education & Income \\
\hline End users & $\begin{array}{l}15 \text { Spain } \\
4 \text { Netherlands } \\
2 \text { Italy } \\
2 \text { France } \\
4 \text { Israel } \\
5 \text { Serbia } \\
3 \text { Slovenia }\end{array}$ & $35(21 \mathrm{~W}, 14 \mathrm{M})$ & $76.3 \pm 8.3$ & $\begin{array}{l}3 \mathrm{P} / \mathrm{S} \\
14 \mathrm{PU} / \mathrm{VT} \\
18 \mathrm{UD}\end{array}$ & $\begin{array}{l}3<10,000 € \\
11 \quad 10,000-20,000 € \\
9 \quad 20,000-30,000 € \\
7 \quad 30,000-40,000 € \\
5>40,000 €\end{array}$ \\
\hline Informal caregivers & $\begin{array}{l}24 \text { Spain } \\
5 \text { Greece } \\
7 \text { Netherlands } \\
5 \text { Italy } \\
11 \text { France } \\
3 \text { Israel } \\
9 \text { Serbia } \\
16 \text { Slovenia }\end{array}$ & $80(45 \mathrm{~W}, 35 \mathrm{M})$ & $46.8 \pm 13.1$ & $\begin{array}{l}1 \mathrm{P} / \mathrm{S} \\
18 \mathrm{PU} / \mathrm{VT} \\
61 \mathrm{UD}\end{array}$ & $\begin{array}{ll}12 & <10,000 € \\
20 & 10,000-20,000 € \\
19 & 20,000-30,000 € \\
10 & 30,000-40,000 € \\
19> & 40,000 €\end{array}$ \\
\hline Formal caregivers & $\begin{array}{l}77 \text { Spain } \\
29 \text { Greece } \\
4 \text { Netherlands } \\
26 \text { Italy } \\
2 \text { France } \\
5 \text { Israel } \\
5 \text { Serbia } \\
1 \text { Slovenia }\end{array}$ & $149(89 \mathrm{~W}, 60 \mathrm{M})$ & $43.3 \pm 12.1$ & $\begin{array}{l}1 \mathrm{P} / \mathrm{S} \\
7 \mathrm{PU} / \mathrm{VT} \\
141 \mathrm{UD}\end{array}$ & 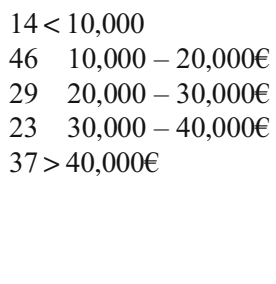 \\
\hline Administration/management staff & $\begin{array}{l}22 \text { Spain } \\
5 \text { Greece } \\
5 \text { Netherlands } \\
9 \text { Italy } \\
7 \text { France } \\
1 \text { Serbia }\end{array}$ & $49(29 \mathrm{~W}, 20 \mathrm{M})$ & $44.7 \pm 11.0$ & $\begin{array}{l}1 \mathrm{P} / \mathrm{S} \\
0 \mathrm{PU} / \mathrm{VT} \\
48 \mathrm{UD}\end{array}$ & $\begin{array}{ll}2<10,000 € \\
10 & 10,000-20,000 € \\
13 & 20,000-30,000 € \\
13 & 30,000-40,000 € \\
12>40,000 €\end{array}$ \\
\hline
\end{tabular}

Note: $\mathbf{n}=$ Sample $; \mathbf{W}=$ Women; $\mathbf{M}=$ Men; $\mathbf{P} / \mathbf{S}=$ Primary/Secondary; $\mathbf{P U} / \mathbf{V T}=$ Pre-university Education/Vocational training; $\mathbf{U D}=$ University degree; S.D. $=$ Standard deviation 


\section{References}

1. United Nations [UN] (2017) World Population Prospects The 2017 Revision Key Findings and Advance Tables. United Nations, New York

2. Statistical Office of the European Union [Eurostat] (2015) People in the EU: who are we and how do we live? Eurostat, Luxembourg

3. Boleaga-Durán B, Patiño Iribe F, Vázquez Fernández V, Chuc M (2012) Neuroimagen del deterioro cognitivo. (Spanish). An Radiol Mex 11:191-199

4. Petersen RC (2011) Mild cognitive impairment. N Engl J Med 364: 2227-2234. https://doi.org/10.1056/NEJMcp0910237

5. Sachdev PS, Lipnicki DM, Kochan NA, et al (2015) The prevalence of mild cognitive impairment in diverse geographical and ethno cultural regions: The COSMIC Collaboration. PLoS One 10:1-19. https://doi.org/10.1371/journal.pone.0142388

6. Petersen RC, Knopman DS, Boeve BF, et al (2009) Mild cognitive impairment: Ten years later. Arch Neurol 66:1447-1455. https:// doi.org/10.1001/archneurol.2009.266.Mild

7. Petersen R, Smith G, Waring S, et al (1999) Mild cognitive impairment: Clinical characterization and outcome. Arch Neurol 56:303308. https://doi.org/10.1001/archneur.56.3.303

8. World Health Organization [WHO] (2017) Demencia. In: WHO. $\mathrm{http}: / / w w w . w h o . i n t / m e d i a c e n t r e / f a c t s h e e t s / f s 362 / \mathrm{es} /$.

9. Victor CR, Bowling A (2012) A longitudinal analysis of loneliness among older people in Great Britain. J Psychol 146:313-31. https:// doi.org/10.1080/00223980.2011.609572

10. Wilson RS, Boyle PA, Segawa E, et al (2013) The influence of cognitive decline on well-being in old age. Psychol Aging 28: 304-313. https://doi.org/10.1037/a0031196

11. Campos W, Martinez A, Sanchez W, et al (2016) A Systematic Review of Proposals for the Social Integration of Elderly People Using Ambient Intelligence and Social Networking Sites. Cognit Comput 8:529-542. https://doi.org/10.1007/s12559-016-9382-z

12. Petersen J, Daniel A, Kaye J, et al (2014) Unobtrusive in-home detection of time spent out-of-home with applications to loneliness and physical activity. IEEE J Biomed Heal Inf 18:1590-1596. https://doi.org/10.1109/JBHI.2013.2294276

13. Cornwell, E.Y. \& Waite LJ (2009) Social Disconnectedness, Perceived Isolation, and Health among Older Ad. Journal Heal Sociol Behav 50:31-48. https://doi.org/10.1177/ 002214650905000103

14. World Health Organization [WHO] (2002) Active Ageing. A Policy Framework World. WHO, Madrid

15. Karr JE, Areshenkoff CN, Rast P, Garcia-Barrera MA (2014) An Empirical Comparison of the Therapeutic Benefits of Physical Exercise and Cognitive Training on the Executive Functions of Older Adults: A Meta- Analysis of Controlled Trials. Neuropsychology 28:829-845. https://doi.org/10.1037/ neu0000101

16. Pinto-Bruno ÁC, García-Casal JA, Csipke E, et al (2017) ICTbased applications to improve social health and social participation in older adults with dementia. A systematic literature review. Aging Ment Health 21:58-65. https://doi.org/10.1080/13607863.2016. 1262818

17. Chen Y-RR, Schulz PJ (2016) The Effect of Information Communication Technology Interventions on Reducing Social Isolation in the Elderly: A Systematic Review. J Med Internet Res 18:e18. https://doi.org/10.2196/jmir.4596

18. Meiland F, Innes A, Mountain G, et al (2017) Technologies to Support Community-Dwelling Persons With Dementia: A Position Paper on Issues Regarding Development, Usability, Effectiveness and Cost-Effectiveness, Deployment, and Ethics. JMIR Rehabil Assist Technol 4:e1. https://doi.org/10.2196/rehab. 6376
19. Almeida OP, Yeap BB, Alfonso H, et al (2012) Older Men Who Use Computers Have Lower Risk of Dementia. PLoS One 7:1-7. https://doi.org/10.1371/journal.pone.0044239

20. Davis FD (1985) A Technology Acceptance Model for Empirically Testing New End-User Information Systems. Massachusetts Inst Technol 291

21. Davis FD (1989) Perceived Ease of Use, and User Acceptance of Information Technology. MIS Q 13:319-340. https://doi.org/10. 2307/249008

22. Dillon A, Morris MG (1996) User acceptance of new information technology: theories and models. In: Annual review of information science and technology. Medford: Information Today, pp 3-32

23. Granata C, Pino M, Legouverneur G, et al (2013) Robot services for elderly with cognitive impairment: Testing usability of graphical user interfaces. Technol Heal Care 21:217-231. https://doi.org/10. 3233/THC-130718

24. García-Betances RI, Cabrera-Umpiérrez MF, Ottaviano M, et al (2016) Parametric Cognitive Modeling of Information and Computer Technology Usage by People with Aging- and Disability-Derived Functional Impairments. Sensors (Basel) 16: 266. https://doi.org/10.3390/s16020266

25. Groves RM, Fowler FJ, Couper MP, et al (2011) Survey Methodology, (2nd ed.). John Wiley \& Sons, Inc., New Jersey

26. International Organization for Standardization [ISO] (2018) ISO 9241-11:2018(en), Ergonomics of human-system interaction Part 11: Usability: Definitions and concepts. https://www.iso.org/ obp/ui/\#iso:std:iso:9241:-11:ed-2:v1:en. Accessed 6 Aug 2018

27. Folstein MF, Folstein SE, McHugh PR (1975) "Mini-mental state": A practical state method for grading the cognitive state of patients for the clinician. J Psychiatr Res 12:189-198. https://doi.org/10. 1016/0022-3956(75)90026-6

28. Etchemendy E, Baños RM, Botella C, Castilla D, Alcañiz M, Rasal P, Farfallini L (2011) An e-health platform for the elderly population: The butler system. Computers \& Education 56 (1):275-279. https://doi.org/10.1016/j.compedu.2010.07.022

29. Castilla D, Garcia-Palacios A, Miralles I, et al (2016) Effect of Web navigation style in elderly users. Comput Human Behav 55:909 920. https://doi.org/10.1016/j.chb.2015.10.034

30. Toribio-Guzmán JM, Parra Vidales E, Viñas Rodríguez MJ, et al (2018) Rehabilitación Cognitiva por Ordenador en Personas Mayores: Programa GRADIOR. Aula 24:61-75. https://doi.org/ 10.14201/aula2018246175

31. Foscolou A, Magriplis E, Tyrovolas S, et al (2018) Lifestyle determinants of healthy ageing in a Mediterranean population: The multinational MEDIS study. Experimental Gerontology 110:35-41. https://doi.org/10.1016/j.exger.2018.05.008

32. Greenaway MC, Duncan NL, Smith GE (2013) The memory support system for mild cognitive impairment: randomized trial of a cognitive rehabilitation intervention. International Journal of Geriatric Psychiatry 28 (4):402-409. https://doi.org/10.1002/gps. 3838

33. Jämsä T, Kangas M, Vikman I, Nyberg L, Korpelainen R (2014) Fall detection in the older people: from laboratory to real-life. Proceedings of the Estonian Academy of Sciences 63 (3):253. https://doi.org/10.3176/proc.2014.3.08

34. Mitzner TL, Rogers WA, Fisk AD, et al (2016) Predicting older adults' perceptions about a computer system designed for seniors. Univers Access Inf Soc 15:271-280. https://doi.org/10.1007/ s10209-014-0383-y

35. Castilla D, Garcia-Palacios A, Bretón-López J, et al (2013) Process of design and usability evaluation of a telepsychology web and virtual reality system for the elderly: Butler. Int J Hum Comput Stud 71:350-362. https://doi.org/10.1016/j.ijhcs.2012.10.017

36. O'Sullivan JL, Gellert P, Hesse B, et al (2018) Exploring attitudes of healthcare professionals towards ICT-based interventions for nursing home residents with dementia. mixed-methods approach. 
Contemp Nurse 54:13-25. https://doi.org/10.1080/10376178.2017. 1421087

37. Ben-Sadoun G, Sacco G, Manera V, et al (2016) Physical and Cognitive Stimulation Using an Exergame in Subjects with Normal Aging, Mild and Moderate Cognitive Impairment. J Alzheimer's Dis 53:1299-1314. https://doi.org/10.3233/JAD160268

38. Goghari VM, Lawlor-Savage L (2018) Self-perceived benefits of cognitive training in healthy older adults. Front Aging Neurosci 10: 1-10. https://doi.org/10.3389/fnagi.2018.00112

39. Pino M, Boulay M, Jouen F, Rigaud AS (2015) "Are we ready for robots that care for us?" Attitudes and opinions of older adults toward socially assistive robots. Front Aging Neurosci 7:1-15. https://doi.org/10.3389/fnagi.2015.00141

40. Yuan S, Hussain SA, Hales KD, Cotten SR (2015) What do they like? Communication preferences and patterns of older adults in the U.S.: The role of technology. Educ Gerontol 1277: 151002110532002. https://doi.org/10.1080/03601277.2015. 1083392

41. Castilla D, Botella C, Miralles I, et al (2018) Teaching digital literacy skills to the elderly using a social network with linear navigation: A case study in a rural area. Int J Hum Comput Stud 118:24 37. https://doi.org/10.1016/j.ijhcs.2018.05.009

42. Haesner M, Steinert A, O'Sullivan JL, Steinhagen-Thiessen E (2015) Evaluating an accessible web interface for older adults the impact of mild cognitive impairment (MCI). J Assist Technol 9:219-232. https://doi.org/10.1108/JAT-11-2014-0032

43. Garcia-Sanjuan F, Jaen J, Nacher V (2017) Tangibot: A tangiblemediated robot to support cognitive games for ageing people-A usability study. Pervasive Mob Comput 34:91-105. https://doi.org/ 10.1016/j.pmcj.2016.08.007
44. Djabelkhir L, Wu Y-H, Vidal J-S, et al (2017) Computerized cognitive stimulation and engagement programs in older adults with mild cognitive impairment: comparing feasibility, acceptability, and cognitive and psychosocial effects. Clin Interv Aging Volume 12:1967-1975. https://doi.org/10.2147/CIA.S145769

45. Salinas-Rodríguez A, Torres-Pereda MDP, Manrique-Espinoza B, et al (2014) Impact of the non-contributory social pension program 70 y más on older adults' mental well-being. PLoS One 9. https:// doi.org/10.1371/journal.pone.0113085

46. United Nations [UN] (2003) Declaración Política y Plan de Acción Internacional de Madrid sobre el Envejecimiento 2002. United Nations, Nueva York

47. Pauly T, Lay JC, Scott SB, Hoppmann CA (2018) Social relationship quality buffers negative affective correlates of everyday solitude in an adult lifespan and an older adult sample. Psychol Aging 33:728-738. https://doi.org/10.1037/pag0000278

48. Navarro E, Calero MD, Calero-García MJ (2014) Diferencias entre hombres y mujeres mayores en funcionamiento cognitivo y calidad de vida. Eur J Investig Heal Psychol Educ 4:267-277. https://doi. org/10.1989/ejihpe.v4i3.74

49. McCarrey An, Y., Kitner-Triolo, M. H., Ferrucci, L. and Resnick, S. M. AC (2016) Sex differences in cognitive trajectories in clinically normal older adults. Psychol Aging 31:166-175. https://doi. org/10.1037/pag0000070

50. Franco Martín MÁ, Orihuela T, Bueno Y, Cid T (2000) Programa GRADIOR: programa de evaluación y rehabilitación cognitiva por ordenador. Edintras, Valladolid

Publisher's Note Springer Nature remains neutral with regard to jurisdictional claims in published maps and institutional affiliations. 